\title{
(c) $(0$
}

Gabriel Radecki

(D) http://orcid.org/0000-0003-1311-5635

Uniwersytet Śląski w Katowicach

\section{Pojęcie wydobywania kopalin ze złóż w kontekście prawa wodnego}

\section{Wstęp}

W ostatnim numerze „Prawnych Problemów Górnictwa i Ochrony Środowiska" Sebastian Wójcik-Jackowski w interesujący sposób zajął się problematyką podwójnej reglamentacji przez przepisy ustaw z dnia 9 czerwca 2011 r. — Prawo geologiczne i górnicze ${ }^{1}$ oraz z dnia 20 lipca 2017 r. — Prawo wodne ${ }^{2}$ działalności polegającej na wydobywaniu z wód powierzchniowych kamieni, żwiru, piasku i innych materiałów, dalej dla uproszczenia określanych także jako kruszywa ${ }^{3}$. Działalność ta może być mianowicie postrzegana zarówno jako wydobywanie kopalin ze złóż w rozumieniu pierwszej z powołanych ustaw, która podlega przewidzianym przez nią wymogom, m.in. łączącym się z obowiązkiem uzyskania koncesji, jak i jako korzystanie z wód, mogące wymagać pozwolenia wodnoprawnego. S. Wójcik-Jackowski już w punkcie wyjścia swoich rozważań nawiązał zarazem do wcześniejszego artykułu, jaki ukazał się na ten temat na łamach PPGiOŚ, podając w wątpliwość przyjęte w nim założenie, że kruszywa stanowią złoże kopaliny ${ }^{4}$. Podsumowując natomiast swój wywód, przyznał, że zagadnie-

${ }^{1}$ Dz.U. 2020, poz. 1064 ze zm., dalej: pr.g.g.

2 Dz.U. 2020, poz. 310 ze zm., dalej: pr.wodn.

3 S. WóJCIK-JACKOwski: Wydobywanie kruszyw z tożyska wody plynącej. „Prawne Problemy Górnictwa i Ochrony Środowiska" 2019, nr 2, s. 61 i n. Jak widać, Autor nawet w tytule opracowania posłużył się zbiorczym pojęciem „kruszywa”, które następnie rozwinął (s. 62).

${ }^{4}$ G. RADECKI: Wydobywanie kopalin z wód powierzchniowych. „Prawne Problemy Górnictwa i Ochrony Środowiska” 2018, nr 1-2, s. 97 i nast. Założenie to zostało jednak opatrzone 
nie pozostaje nadal otwarte, co można potraktować jako zaproszenie do dalszej dyskusji i do jej kontynuacji w kolejnym opracowaniu, składającym się już przez to na cykl publikacji naświetlających zagadnienie $\mathrm{z}$ różnych perspektyw i wyodrębniających się w zwarty wątek tematyczny, jaki Czytelnik PPGiOŚ mógłby prześledzić. Stanowisko S. Wójcika-Jackowskiego, które nie budzi zastrzeżeń, zwłaszcza jeśli chodzi o analizę przepisów Prawa wodnego i specjalistycznych kwestii hydrologicznych, skłania zaś do dalszych refleksji, szczególnie z punktu widzenia Prawa geologicznego i górniczego. Refleksje te, ze względu na przedstawioną tezę wyjściową, negującą — jak się okaże, w przeważającym stopniu słusznie - uznanie materiałów wydobytych z wód za złoża kopalin, muszą mieć charakter głównie terminologiczny i koncentrować się na wyjaśnieniu treści i zakresu pojęć, które w istocie mają zasadnicze znaczenie dla zastosowania do określonej działalności przepisów Prawa geologicznego i górniczego regulujących wydobycie kopalin ze złóż. Zależy to bowiem od ustalenia po pierwsze, że przedmiotem działalności jest kopalina, po drugie że kopalina znajduje się w złożu i po trzecie - że działalność polega na wydobyciu. Dopiero wówczas można też rozstrzygać ewentualną kolizję pomiędzy Prawem geologicznym i górniczym a Prawem wodnym, która wchodzi przecież w rachubę jedynie wtedy, gdy dany stan faktyczny wyczerpuje hipotezy przepisów zamieszczonych w obu tych aktach prawnych. Problem zbiegu tych przepisów w rozpatrywanej materii powstaje wszak, gdy jedna działalność może być kwalifikowana jednocześnie jako korzystanie $\mathrm{z}$ wód i wydobywanie kopalin ze złóż.

W opracowaniu zostaną omówione trzy przywołane wyżej pojęcia, z niezbędnym uwzględnieniem Prawa wodnego. Wcześniej jednak, tytułem krótkiego wprowadzenia merytorycznego, przedstawienia wymaga problem, który S. Wójcik-Jackowski zamierzał rozstrzygnąć, i wcześniejsze próby podejmowane w doktrynie w tym zakresie. Pozwoli to ocenić, czy i w jakim stopniu problem ten został rozwiązany.

\section{Koncepcje na temat zbiegu przepisów dotyczących działalności wydobywczej}

Zgodnie $\mathrm{z}$ art. 1 pkt 2 pr.gg. ustawa ta określa zasady i warunki podejmowania, wykonywania oraz zakończenia działalności w zakresie wydobywania kopalin ze złóż. W szczególności działalność ta, jak zastrzeżono w art. 21 ust. 1 pkt 2 pr.g.g., może być wykonywana po uzyskaniu koncesji. Jednocześnie jed-

pewnymi zastrzeżeniami, które pokrywają się z przedstawionymi dalej poglądami S. Wójcika-Jackowskiego (zob. s. 98-99). 
nak, o czym wspomniano wyżej, wydobywanie kruszyw z wód powierzchniowych w art. 34 pkt 8 pr.wodn. uznane jest za rodzaj szczególnego korzystania z wód, które stosownie do art. 389 pkt 2 pr.wodn. wymaga pozwolenia wodnoprawnego. W tym kontekście przywołać wypada treść art. 3 pkt 1 pr.g.g., w myśl której ustawy tej nie stosuje się do korzystania z wód w zakresie uregulowanym odrębnymi przepisami. W konsekwencji w literaturze opowiedziano się za możliwością wydobywania kopalin z pominięciem rygorów prawa geologicznego i górniczego ${ }^{5}$. Zwrócono jednak również uwagę, że art. 3 pkt 1 pr.g.g. stanowi dokładny odpowiednik art. 4 pkt 1 nieobowiązującej już ustawy z dnia 4 lutego 1994 r. - Prawo geologiczne i górnicze ${ }^{6}$, na gruncie której utrwaliło się jednolite stanowisko, zachowujące aktualność w obecnym stanie prawnym, iż podmiot wydobywający kruszywa z wód powinien uzyskać zarówno pozwolenie wodnoprawne, jak i koncesję ${ }^{7}$. W związku z tym w doktrynie zaprezentowano koncepcje mające w odniesieniu do tej działalności rozdzielić zakresy zastosowania obu rozpatrywanych aktów prawnych w drodze ich wykładni.

Pierwsza z nich dotyczyła wydobycia kruszyw z akwenów eksploatacyjnych, czyli sztucznych zbiorników wodnych powstałych w wyniku działalności wydobywczej. Zdaniem jej Autora rozstrzygający jest moment rozpoczęcia wydobycia: jeżeli akwen wówczas jeszcze nie istnieje, lecz powstaje podczas prowadzonych robót, to nie dochodzi do szczególnego korzystania z wód ${ }^{8}$.

${ }^{5}$ A. LıPIŃsKi: Z problematyki nielegalnego wydobywania kopalin. W: Prawne aspekty gospodarowania zasobami środowiska. Korzystanie z zasobów środowiska. Red. K. KARPus, B. Rakoczy, M. Szalewska. Toruń 2014, s. 266. Autor sprecyzował i rozwinął później to stanowisko, stwierdzając, że pomimo iż Prawo wodne zachowuje charakter szczególny w stosunku do Prawa geologicznego i górniczego, wyłączając przewidziane nim rygory, to jednak otwarta pozostaje kwestia, czy dotyczy to wszelkich rodzajów korzystania z wód, czy tylko korzystania powszechnego i zwykłego — zob. A. LipiŃski. W: Zrównoważony rozwój jako czynnik determinujacy prawne podstawy zarzadzania geologicznymi zasobami środowiska. Red. G. DobroWOLSKI. Katowice 2016, s. 46. W efekcie podał w wątpliwość możliwość zastosowania reguły kolizyjnej wynikającej z art. 3 pkt 1 pr.g.g. do omawianego tu szczególnego korzystania z wód. Możliwość tę następnie wprost wykluczył, podkreślając, że wydobywanie kruszywa (innych materiałów) z wód (a właściwie spod wód) wymaga spełnienia przesłanek przewidzianych oboma omawianymi ustawami — zob. w: G. Dobrowolski, A. LipińsKi, R. Mikosz, G. RADECKI: Gospodarowanie geologicznymi zasobami środowiska w świetle zasady zrównoważonego rozwoju. Zagadnienia prawne. Katowice 2018, s. 56.

${ }^{6}$ Dz.U. 2005, nr 228, poz. 1947 ze zm.

${ }^{7}$ Ł. IwAŃSKI: Wybrane aspekty wydobywania kruszywa naturalnego ze złóż zlokalizowanych na lub pod dnem akwenów na śródladowych wodach powierzchniowych. W: Prawne aspekty gospodarowania zasobami środowiska. Korzystanie z zasobów środowiska. Red. K. KARPUS, B. Rakoczy, M. Szalewska. Toruń 2014, s. 176-177. Por. przegląd argumentów mających wspierać to stanowisko - G. RADECKI: Wydobywanie kopalin..., s. 104-105.

${ }^{8}$ Ł. IWAŃsKI: Wybrane aspekty wydobywania kruszywa naturalnego ze złóż zlokalizowanych na lub pod dnem akwenów na śródlądowych wodach powierzchniowych. W: Prawne aspekty..., s. 182. 
Następne zapatrywanie, które wypada podtrzymać, sprowadza się do wniosku wyprowadzonego z zestawienia treści art. 23 ust. 1 pkt 2 pr.g.g. i art. 34 pkt 8 pr.wodn., przypisującego znaczenie sposobowi wydobycia9. W świetle pierwszego $\mathrm{z}$ tych przepisów udzielenie koncesji na wydobywanie kopalin z gruntów pod wodami śródlądowymi wymaga opinii organu właściwego do wydania pozwolenia wodnoprawnego, z kolei w drugim z nich, jak już wspomniano, mowa o wydobywaniu $\mathrm{z}$ wód. Wydobycie kopalin $\mathrm{z}$ gruntu pod wodami na podstawie koncesji nie musi się odbywać od strony wód, z dostępem do nich, lecz przez drążenie wyrobisk pod dnem zbiornika wodnego, będących odnogami szybu wykonanego na brzegu. Opinia organu właściwego do wydania pozwolenia wodnoprawnego miałaby $\mathrm{w}$ takim przypadku na celu uwzględnienie uwarunkowań związanych z ochroną zbiornika i byłaby zbędna, gdyby ta sama działalność wymagała również tego pozwolenia. Formą szczególnego korzystania z wód byłoby natomiast wydobycie wykonywane od strony lustra wody, poprzez wybieranie złoża kopaliny zalegającego na dnie lub pod dnem zbiornika wodnego.

S. Wójcik-Jackowski również uznał, że powyższa rozbieżność terminologiczna jest kluczowa $\mathrm{w}$ omawianym zakresie, wszelako wyprowadził $\mathrm{z}$ niej nieco inne konkluzje. Stwierdził mianowicie, że „oczywiście nie chodzi (...) o sposób realizacji robót (np. za pomocą koparek pracujących z lądu i znajdujących się na skarpie brzegowej, ale o to, gdzie występuje kruszywo przewidziane do pozyskania"10. Jego zdaniem w odróżnieniu do art. 23 ust. 1 pkt 2 pr.g.g wydobycie $\mathrm{z}$ wód w rozumieniu art. 34 pkt 8 pr.wodn. odnosi się do wód, a nie gruntów pod wodami, i do kruszyw, których nie można uznać za złoża kopalin ${ }^{11}$. Dotyczy to jednak jedynie wód płynących, których łożysko stanowi po pierwsze swoistą część składową cieku wodnego i po drugie pewną zmienną, na skutek działania m.in. nurtu rzeki ${ }^{12}$. Tym samym koncepcja ta, tak jak ta omówiona jako pierwsza, ogranicza się do wydobycia prowadzonego ze ściśle określonych rodzajów wód powierzchniowych i nie ma przez to charakteru całościowego, nie pozwalając rozstrzygnąc analizowanej kolizji w wypadku wód powierzchniowych stojących ${ }^{13}$. W związku z tym podkreślenia wymaga, że w treści art. 34 pkt 8 pr.wodn. tej ostatniej kategorii wód nie wyłączono z zakresu jego zastosowania, lege non distinguente obejmując nim wszystkie wody powierzchniowe. Nie należy również tracić z pola widzenia, że rozdzielenie wód powierzchniowych płynących od wód powierzchniowych stojących nie zawsze jest zadaniem łatwym ze względu na fakt, iż niektóre prawne kryteria podziału wspomnia-

\footnotetext{
9 G. RADECKI: Wydobywanie kopalin..., s. 105-106.

${ }^{10}$ S. Wóıсік-ЈАС́ошsкi: Wydobywanie kruszyw..., s. 63.

${ }^{11}$ Ibidem, s. $66-67$.

${ }^{12}$ Ibidem, s. 63-65, 69.

${ }^{13}$ Zauważył to zresztą jej Autor - S. Wójcik-Jackowski, zob. ibidem, s. 69.
} 
nych wód są inne od tych wykorzystywanych w hydrologii ${ }^{14}$. W literaturze trudności $\mathrm{w}$ tej materii zilustrowano przykładem jeziora, które $\mathrm{w}$ oderwaniu od jakichkolwiek uwarunkowań środowiskowych i bez dokonania koniecznych do tego obserwacji i pomiarów terenowych w przeważającej części zakwalifikowano jako wodę płynącą, a w pozostałej jako stojącą ${ }^{15}$. Z punktu widzenia tematu opracowania poważniejsza wątpliwość zamyka się wszelako w pytaniu o to, czy na pewno uznanie kruszywa za element cieku wodnego i zmienność jego położenia, warunkowana przemieszczaniem się tego cieku, wyłącza po pierwsze jego kwalifikację jako złoża kopaliny, a po drugie pozyskania kruszywa jako wydobycia tej kopaliny ze złoża. Wyjaśnienie tej kwestii wymaga nawiązania do przepisów Prawa geologicznego i górniczego celem ustalenia treści i zakresu tych pojęć.

\section{Kopalina}

Pojęcie „kopalina” wprowadzono do polskiego systemu prawnego w dekrecie z dnia 6 maja 1953 r. - Prawo górnicze ${ }^{16}$. We wcześniej obowiązującym Prawie górniczym ${ }^{17}$ występowało pojęcie minerału. Zdaniem Tadeusza Płodowskiego zmiana ta nie miała charakteru wyłącznie terminologicznego, gdyż pojęcie „minerał” właściwe jest nauce geologii, podczas gdy kopalina, czyli ciało, które się wydobywa ze złóż i się do tego wydobycia nadaje, jest punktem wyjścia do ustalenia pojęcia górnictwa, nadając eksploatacji cechy działalności górniczej $^{18}$. Doktryna nie podzieliła jednak tego poglądu, stwierdzając, że nie znajduje on dostatecznych podstaw prawnych ${ }^{19}$. Antoni Agopszowicz zaznaczył, że o ile o minerale wiedziano, iż jest to skałotwórczy pierwiastek lub związek chemiczny, o tyle o kopalinie nie wiedziano nic poza określeniem go jako ciało stałe, które można kopać, odspajać od złoża, z dopuszczeniem objęcia tym pojęciem,

14 Tak M. Marszelewski, W. Marszelewski: Problemy własności jezior w Polsce. „Przegląd Prawa Ochrony Środowiska” 2013, nr 3, s. 32 oraz 35 i n. Autorzy, zaznaczając, że z hydrologicznego punktu widzenia każde jezioro jest wodą stojącą, na gruncie wcześniejszego stanu prawnego poddali krytyce kryterium ciągłych bądź okresowych naturalnych dopływów lub odpływów wód powierzchniowych, które również w świetle art. 22 pkt 2 pr.wodn. decyduje o zaliczeniu jezior oraz innych naturalnych zbiorników wodnych do śródlądowych wód płynących.

${ }^{15}$ M. Marszelewski, W. Marszelewski: Jezioro Rododzierz — przyklady wykluczajacych się rodzajów własności. „Przegląd Prawa Ochrony Środowiska” 2014, nr 1, s. 105 i 110.

${ }^{16}$ Dz.U. nr 29, poz. 113, t.j. Dz.U. 1978, nr 4, poz. 12 ze zm.

17 Rozporządzenie Prezydenta Rzeczypospolitej Polskiej z dnia 29 listopada 1930 r., Dz.U. nr 85, poz. 654 , ze zm.

18 T. PŁodowski: Prawo górnicze. Warszawa 1961, s. 71-72.

19 A. Agopszowicz: Prawo wydobywania kopalin. „Ruch Prawniczy Ekonomiczny i Społeczny” 1966, nr 3, s. 22 oraz A. LipiŃski: Własność złóż kopalin. „Studia Cywilistyczne” 1977, T. 28 , s. 175. 
wbrew jego znaczeniu semantycznemu, także ciał ciekłych i gazowych ${ }^{20}$. Uznał zatem kopalinę za synonim minerału (surowca mineralnego) i część (nie część składową) gruntu lub górotworu ${ }^{21}$. Odnotowania wymaga jednak również trafne spostrzeżenie Ryszarda Mikosza, że żaden przepis prawa nie definiuje pojęcia „minerał”, co dodatkowo potęguje trudności interpretacyjne ${ }^{22}$. Odniesione ono zostało do ustawowej definicji złoża kopaliny, do której wypadnie jeszcze powrócić. W tym miejscu zaznaczyć natomiast warto, że w definicji tej, w obecnie obowiązującym stanie prawnym zamieszczonej w art. 6 ust. 1 pkt 19 pr.g.g., mowa o naturalnym nagromadzeniu nie tylko minerałów, ale i skał oraz innych substancji ${ }^{23}$. Dowodzi to, że zamiarem ustawodawczym było objęcie prawem górniczym kopalin wszystkich rodzajów ${ }^{24}$, które znajdują się w obrębie skorupy ziemskiej $^{25}$. Nie zdefiniowano zarazem samej kopaliny, jedynie w załączniku do ustawy Prawo geologiczne i górnicze, określającym stawki opłaty eksploatacyjnej, zgodnie z art. 134 ust. 1 pr.g.g. ponoszonej za wydobywanie kopalin ze złóż, wymieniono ich rodzaje, choć w sposób niewyczerpujący, skoro załącznik zamyka stawka przewidziana dla kopalin innych niż wyszczególnione wcześniej ${ }^{26}$. Załącznik obejmuje kopaliny $\mathrm{w}$ różnych stanach skupienia ${ }^{27}$ i reprezentujących wiele rodzajów ujętych w 67 punktów, w tym takich zaliczających się do kru$\mathrm{szyw}^{28}$. Niewątpliwie zatem wydobywanie kruszyw zawsze stanowi wydobywanie kopalin, także wtedy, gdy następuje z wód powierzchniowych ${ }^{29}$. Prawo geo-

20 A. Agopszowicz: Prawo górnicze..., s. 21-22.

${ }^{21}$ Ibidem; A. Agopszowicz: Zarys systemu prawnego górnictwa. Katowice 1986, s. 37. Analogicznie pisze A. LipıŃski. W: Zrównoważony rozwój..., s. 42.

${ }^{22}$ R. Mikosz. W: System prawa prywatnego. T. 3: Prawo rzeczowe. Red. E. GNiewek. Warszawa 2013, s. 456.

${ }^{23}$ Zob. omówienie tych trzech pojęć przez S. WóJCIKA-JACKowskiego: Wydobywanie kruszyw..., s. 62.

${ }^{24}$ A. Lipiński, R. Mikosz: Ustawa prawo geologiczne i górnicze. Komentarz. Warszawa 2003, s. 28 - 29. Wyjaśnienia wymaga jednak, że Autorzy odnieśli ten pogląd do wcześniejszego stanu prawnego, wynikającego z powołanego już Prawa górniczego z dnia 6 maja 1953 r., w którym wyróżniano kopaliny „poddane” i „niepoddane” temu prawu.

25 A. LipiŃski: Użytkowanie górnicze. Kraków 1996, s. 71. Autor zauważył słusznie, że dyskusyjne jest przeciwstawienie sobie w ramach omawianej definicji ustawowej minerałów skał oraz innych substancji.

${ }^{26}$ Zob. A. LipIŃski: Plan ruchu zakładu górniczego jako instrument ochrony środowiska. W: Administracja a środowisko. Prace dedykowane prof. zw. dr. hab. Markowi Górskiemu z okazji jubileuszu 45-lecia pracy naukowej. Red. A. BarczaK, P. Korzeniowski. Szczecin 2018, s. 218 i IDEM: Prawne podstawy geologii i górnictwa. Warszawa 2019, s. 31.

27 Przykładowo mowa w nim o gazach szlachetnych (pkt 10a) i ropie naftowej (pkt 36 i 36a).

${ }^{28} \mathrm{~W}$ punkcie 33 załącznika przewidziano stawkę opłaty eksploatacyjnej dla piasków i żwirów — zob. S. WóJcik-JACKowski: Wydobywanie kruszyw..., s. 65 (w przypisie).

${ }^{29}$ G. RADECKI: Wydobywanie kopalin..., s. 99. Por. również uwagi wyjaśniające użycie słowa „kopalina” w tytule tego opracowania (s. 97). W nauce prawa górniczego od dawna prezentowany jest pogląd, że przedmiotem wydobycia prowadzonego w ramach korzystania z wód są kopaliny w rozumieniu prawa górniczego — zob. A. Agopszowicz: Zarys systemu prawnego..., s. 31. 
logiczne i górnicze znajduje jednak do niego zastosowanie wyłącznie wówczas, gdy kopalinę tę wydobywa się ze złoża w rozumieniu jego art. 6 ust. 1 pkt 19.

\section{Złoże kopaliny}

W przywołanym przepisie złoże kopaliny zdefiniowano jako naturalne nagromadzenie minerałów, skał oraz innych substancji, których wydobywanie może przynieść korzyść gospodarczą. Przesłankę korzyści gospodarczej można pominąć jako zbędną i całkowicie nieprzydatną z powodu jej względności i uzależnienia od wielu zmiennych okoliczności, jak potrzeby gospodarki, dostępność określonych technologii itp. ${ }^{30}$. To, że możliwość uzyskania takich korzyści jest nierealna, nie pozwala wykluczyć jej powstania w przyszłości ${ }^{31}$.

Dalej zaakcentować trzeba, że przytoczona definicja nie przewiduje wymogu, by nagromadzenie kopaliny tworzące złoże miało charakter stabilny, a więc zajmowało przestrzeń o stałych granicach. Złoża podlegają przecież przeobrażeniom i przesunięciom, np. wskutek ruchów tektonicznych ${ }^{32}$. Szczególnie w przypadku kopalin o sypkiej konsystencji często dochodzi do jej przemieszczania się w obrębie złoża lub nawet do czasowego jej odłączenia i późniejszego z nim połączenia w wyniku procesów naturalnych, np. samoistnego oberwania się skarpy lub działalności górniczej (przykładowo zasypania przegłębienia w kopalni odkrywkowej piaskiem wybranym z innej części złoża) ${ }^{33}$. Dlatego takie kopaliny o strukturze mniej zwartej tworzą złoża o granicach niejako płynnych, niedających się łatwo określić i kształtowanych przez czynniki zewnętrzne ${ }^{34}$. Wydaje się, że jednym z tych czynników może być nurt rzeki oddziałujący na złoże kruszywa zalegającego na jej dnie.

Oczywiście, zgodzić się wypada ze spostrzeżeniem, w myśl którego pewna trwałość lokalizacji wynika z samego językowego znaczenia słowa „,nagromadzenie"35. Trwałością tą w świetle art. 6 ust. 1 pkt 19 pr.g.g. złoże musi odznaczać się jednak w takim stopniu, który umożliwia wydobywanie z niego kopaliny z korzyścią gospodarczą. Bez znaczenia pozostaje zaś to, czy można precyzyjnie oznaczyć położenie, skład i inne właściwości złoża. Nagromadzenie kopalin jest bowiem ich złożem, niezależnie od tego, czy zostało, a nawet

${ }^{30}$ A. LipiŃski, R. MikosZ: Ustawa prawo geologiczne i górnicze..., s. 42-43.

${ }^{31}$ Zob. np. A. LipIŃski: Prawne podstawy geologii i górnictwa..., s. 30-31; IDEM: Z problematyki nielegalnego wydobywania kopalin. W: Prawne aspekty..., s. 267.

${ }^{32}$ H. Schwarz: Prawo geologiczne i górnicze. Komentarz. T. 1. Wrocław 2013, s. 487.

${ }^{33}$ Ibidem, s. 78

${ }^{34}$ G. RADECKI: Oplata podwyższona za naruszenie warunków wydobywania piasków $i$ żwirów na własne potrzeby. W: Prawne aspekty gospodarowania zasobami środowiska. Korzystanie z zasobów środowiska. Red. K. Karpus, B. Rakoczy, M. Szalewska. Toruń 2014, s. 294-295.

${ }^{35}$ S. Wóscik-JАCKOWsкi: Wydobywanie kruszyw..., s. 63. 
czy w ogóle może być udokumentowane. Dopuszcza się zresztą pewien margines błędu, jakim może być dotknięta dokumentacja geologiczna złoża kopaliny, według art. 89 ust. 1 pr.g.g. sporządzana w celu określenia granic złoża, jego zasobów geologicznych, warunków występowania oraz określenia możliwości wydobycia kopaliny ze złoża ${ }^{36}$. Zakłada się też różne poziomy szczegółowości dokumentacji, np. jeżeli ma ona być podstawą uzyskania koncesji, stopień rozpoznania złoża ma umożliwić sporządzenie projektu zagospodarowania złoża (art. 89 ust. 4 pr.g.g.) ${ }^{37}$. Dokładniejsze rozpoznanie złoża powinno być odnotowane $\mathrm{w}$ ewidencji zasobów złoża kopaliny prowadzonej przez podmiot wykonujący działalność na podstawie koncesji (art. 101 ust. 1 pkt 1 pr.g.g.). Tym samym maksimum wiedzy na temat złoża uzyskuje się w wyniku wybrania jego zasobów, czyli po zakończeniu wydobycia ${ }^{38}$.

Definicja przewidziana w art. 6 ust. 1 pkt 19 pr.g.g. zawiera natomiast zastrzeżenie, że złożem kopaliny może być wyłącznie takie jej nagromadzenie, które jest naturalne, czyli powstałe bez ingerencji człowieka ${ }^{39}$, utworzone i ukształtowane w wyniku procesów geologicznych ${ }^{40}$. W konsekwencji jeżeli nagromadzenie to ma charakter sztuczny, stanowiąc tzw. złoże antropogeniczne, to nie podlega rygorom Prawa geologicznego i górniczego ${ }^{41}$. Omawiany wymóg ma kluczowe znaczenie podczas prawnej kwalifikacji nagromadzeń kruszywa w ciekach wodnych, które zazwyczaj w większym lub mniejszym stopniu, bezpośrednio lub pośrednio, były przedmiotem różnorodnych przedsięwzięć, w tym przekładających się na stan tych nagromadzeń ${ }^{42}$. Dokładne ustalenie liczby tych działań, ich przebiegu i, co najważniejsze, następstw dla cieku jest z pewnością

${ }^{36} \mathrm{~W} \S 6$ ust. 1 rozporządzenia Ministra Środowiska z dnia 1 lipca 2015 r. w sprawie dokumentacji geologicznej złoża kopaliny, z wyłączeniem złoża węglowodorów (Dz.U. 2015, poz. 987), w dokumentacji geologicznej złoża kopaliny dla złóż kopalin stałych stosuje się następujące kategorie rozpoznania złoża kopaliny lub jego części: D, C2, C1, B, przy czym np. w przypadku tej pierwszej kategorii błąd oszacowania średnich wartości parametrów złoża i zasobów może przekraczać $40 \%$ ( 6 ust. 2 pkt 1 rozporządzenia).

${ }^{37}$ Znamienna w rozpatrywanym zakresie jest różnica pomiędzy poszukiwaniem, mającym na celu ustalenie i wstępne udokumentowanie złoża kopaliny (art. 6 ust. 1 pkt 7 pr.g.g.) a rozpoznawaniem, prowadzonym na obszarze tak wstępnie udokumentowanego złoża kopaliny (art. 6 ust. 1 pkt 13 pr.g.g). Zgodnie z art. 26 ust. 3 pr.g.g. projekt zagospodarowania złoża określa wymagania w zakresie racjonalnej gospodarki złożem kopaliny i stanowi załącznik do wniosku o udzielenie koncesji na wydobywanie kopalin ze złóż.

${ }^{38}$ A. LipIŃski: Plan ruchu zakładu górniczego jako instrument ochrony środowiska. W: Administracja a środowisko..., s. 219.

39 A. LipiŃski: Prawne podstawy geologii i górnictwa..., s. 31.

40 T. PŁodowski: Prawo górnicze..., s. 100. Autor odróżnił złoże kopaliny, zalegające w sposób naturalny na powierzchni lub we wnętrzu ziemi, będące pojęciem górniczym, od złoża, będącego pojęciem geologicznym, oraz od złoża sztucznego (zmagazynowanych składów kopaliny już wydobytej).

${ }^{41}$ A. Lipiński, R. Mikosz: Ustawa prawo geologiczne i górnicze..., s. 43.

${ }^{42}$ A. LipińsKi. W: Zrównoważony rozwój..., s. 42. 
bardzo trudne, o ile w ogóle możliwe. W literaturze wskazuje się przykłady wód śródlądowych, co do których można jedynie z dużym prawdopodobieństwem zakładać, że w wyniku licznych prac melioracyjnych przeprowadzanych przez ponad 150 lat doszło do zastąpienia sztucznym dopływem dopływu naturalnego i do antropogenicznej zmiany odpływu ${ }^{43}$. Nie ulega jednak wątpliwości, że osady denne rzeki przemieszczane w związku z jej regulacją nie mogą być uznane za złoże kopaliny w rozumieniu art. 6 ust. 1 pkt 19 pr.g.g. ${ }^{44}$. W efekcie wydobywanie tych kopalin nie następuje ze złoża i nie podlega rygorom Prawa geologicznego i górniczego, chociaż pozostaje wydobywaniem z wód, o którym mowa w art. 34 pkt 8 pr.wodn.

\section{Wydobywanie}

Nie zawsze jednak można jednoznacznie ustalić, kiedy dochodzi do wydobywania kopaliny. W art. 6 ust. 1 pkt 3 pr.g.g. wskazano wprawdzie, że kopalina wydobyta to całość kopaliny odłączonej od złoża, lecz definicja ta nie może uchodzić za przydatną ${ }^{45}$. Poza sporem pozostaje przecież, że samo odłączenie kopaliny od złoża w wyniku określonych działań nie stanowi jedynego warunku pozwalającego uznać te działania za wydobywanie ${ }^{46}$. Taki sam skutek może bowiem pociągnąć za sobą innego rodzaju działalność polegająca np. na wykonaniu wykopów czy niwelacji terenu w trakcie procesu budowlanego, a także służącej założeniu stawu rybnego ${ }^{47}$. Nierzadko zresztą podejmowana jest ona pozornie lub rzeczywiście w innym celu niż deklarowany po to, by ukryć zamiar faktyczny, w szczególności sprowadzający się do pozyskania kopaliny bez konieczności ubiegania się o koncesję ${ }^{48}$. Dlatego ten rzeczywisty zamiar ma znaczenie przesądzające, sprawiając, że wydobywaniem kopalin jest wyłącz-

${ }^{43}$ M. Marszelewsiri, W. Marszelewski: Jezioro Rododzież..., s. 108-110.

${ }^{44}$ A. Lipiński. W: G. Dobrowolski, A. Lipiński, R. Mikosz, G. Radecki: Gospodarowanie geologicznymi zasobami środowiska..., s. 52 (przypis).

${ }_{45}$ Tak np. A. LipIŃski: Prawne podstawy geologii i górnictwa..., s. 31.

${ }^{46}$ G. RADECKI: Opłata podwyższona za naruszenie warunków wydobywania piasków i żwirów na własne potrzeby. W: Prawne aspekty..., s. 295. Konstatację tę potwierdza definicja wydobywania węglowodorów ze złóż, zamieszczona w art. 6 ust. 1 pkt 16c pr.g.g., według której chodzi o prowadzenie wydobycia węglowodorów, w tym przygotowanie wydobytych węglowodorów do transportu oraz ich transport w obrębie zakładu górniczego. W konsekwencji wydobycie to nie ogranicza się do samego oddzielenia kopaliny od złoża, ale obejmuje inne jeszcze czynności niezbędne do jej pozyskania i późniejszego wykorzystania.

${ }^{47}$ Por. A. LipIŃsKI: Z problematyki nielegalnego wydobywania kopalin. W: Prawne aspekty..., s. $264-267$.

${ }^{48}$ H. Schwarz: Prawo geologiczne i górnicze..., s. 43-44. Autor powołał orzecznictwo, w świetle którego ten faktyczny zamiar musi być niezbicie wykazany poprzez wykluczenie, że rzeczywisty zamiar inwestora istotnie odbiegał od zamiaru deklarowanego, np. budowy stawu. 
nie działalność prowadzona $\mathrm{w}$ celu pozyskania kopaliny ${ }^{49}$. Zamiar ten należy rekonstruować na podstawie okoliczności obiektywnych, zwłaszcza tych, które obrazują sposób, w jaki kopalina odłączona od złoża została spożytkowana ${ }^{50}$.

Można powziąć wątpliwość, czy powyższe spostrzeżenia można odnieść również do wydobywania kruszyw (kopalin) w ramach szczególnego korzystania $\mathrm{z}$ wód. $\mathrm{Z}$ jednej strony trudno bowiem uznać za wydobycie wybrania kruszywa zalegającego na dnie zbiornika wodnego niejako przy okazji innych działań, szczególnie jeśli wykonywane są one na podstawie i w granicach prawa. Upoważnieniem do tych działań może być zresztą pozwolenie wodnoprawne inne niż to przewidziane w art. 389 pkt 2 pr.wodn., uprawniające do szczególnego korzystania $\mathrm{z}$ wód, np. dotyczące wykonania urządzeń wodnych czy regulacji wód, zabudowy potoków górskich oraz kształtowania nowych koryt cieków naturalnych (art. 389 pkt $6-7$ pr.wodn.). Z drugiej strony jednak zgodnie $\mathrm{z}$ art. 394 ust. 1 pkt 12 pr.wodn. zgłoszenia wodnoprawnego - będącego, tak jak pozwolenie wodnoprawne, jedną $\mathrm{z}$ form udzielenia zgody wodnoprawnej (art. 388 ust. 1 pr.wodn.) - wymaga wydobywanie kamienia, żwiru, piasku, innych materiałów $\mathrm{z}$ wód $\mathrm{w}$ związku $\mathrm{z}$ utrzymywaniem wód, śródlądowych dróg wodnych oraz remontem urządzeń wodnych, wykonywane w ramach obowiązków właściciela wód ${ }^{51}$. Zakładając, że w Prawie wodnym posłużono się pojęciem „wydobywanie” w jednakowym znaczeniu, wypada przyjąć, iż oznacza ono działalność, dla której pozyskanie kopaliny nie jest głównym celem. Wydaje się, że podyktowane to było potrzebą racjonalnego wydobywania zasobów wydobywanych $\mathrm{z}$ dna cieków wodnych ${ }^{52}$. Zbieg przepisów Prawa geologicznego i górniczego oraz art. 34 pkt 8 pr.wodn. wchodzi jednak w rachubę wyłącznie wtedy, gdy wydobycie w ramach szczególnego korzystania z wód jest prowadzone w zamiarze pozyskania kopaliny.

\section{Uprawnienia górnicze i próba podsumowania}

Dotychczasowe wywody prowadzą do wniosku, że zasadnicza różnica pomiędzy rozpatrywanymi aktami prawnymi sprowadza się do tego, że Prawo geologiczne i górnicze reguluje wyłącznie wydobywanie kopalin znajdujących

49 Zob. np. A. LipiŃski, R. Mikosz: Ustawa prawo geologiczne i górnicze..., s. 14 oraz A. LipiŃski: Komentarz do art. 6-9 ustawy z dnia 9 czerwca 2011 r. Prawo geologiczne i górnicze. „Prawne Problemy Górnictwa i Ochrony Środowiska” 2017, nr 1, s. 15.

${ }^{50}$ G. RADECKI: Oplata podwyższona za naruszenie warunków wydobywania piasków i żwirów na własne potrzeby. W: Prawne aspekty..., s. 295-296.

${ }^{51}$ Zob. S. WóJCIK-JACKOwsKI: Wydobywanie kruszyw..., s. 67-69.

${ }_{52} \mathrm{~W}$ art. 277 ust. 2 pkt 1 lit. f pr.wodn. zobowiązano Radę Ministrów do uwzględniania tej potrzeby podczas określania $\mathrm{w}$ drodze rozporządzenia jednostkowych stawek opłat za tę działalność. 
się w złożu, podczas gdy z punktu widzenia art. 34 pkt 8 pr.wodn. tego rodzaju lokalizacja kopaliny nie jest istotna. Obie ustawy dotyczą tej samej działalności (o ile podejmowana ona jest w celu pozyskania kopaliny), gdy kopalina zalega w złożu w rozumieniu art. 6 ust. 1 pkt 19 pr.g.g. Jeżeli natomiast tego rodzaju złoże występuje na gruncie pod wodą śródlądową lub w nim, to bez znaczenia dla jego statusu, określonego przez Prawo geologiczne i górnicze, pozostaje jego kwalifikacja prawna wynikająca z Prawa wodnego. Naturalne nagromadzenie kopalin nie przestaje być ich złożem i nie zostaje wyłączone z zakresu desygnatów definicji ustawowej tego pojęcia $\mathrm{z}$ tego powodu, że podlega równocześnie unormowaniu innej ustawy, np. jako część koryta czy łożyska wody płynącej. Takie nagromadzenie zalegające na dnie wód śródlądowych lub pod nim stanowi złoże kopaliny nadające się do eksploatacji odkrywkowej ${ }^{53}$. Jednocześnie w doktrynie prawa górniczego od dawna prezentuje się jednolite stanowisko, że formuła wydobywanie kopalin $\mathrm{z}$ wód, obecnie występująca $\mathrm{w}$ art. 34 pkt 8 pr.wodn., oznacza w istocie wydobywanie ich z gruntów pod wodami ${ }^{54}$.

Prawo wodne zresztą również odróżnia wody od gruntów pod nimi, bynajmniej tych pojęć nie utożsamiając i nie łącząc $\mathrm{w}$ jakąś jednorodną jurydyczną całość. Już w art. 2 pr.wodn. wyodrębniono obie te kategorie, podkreślając, że ustawa reguluje sprawy własności wód oraz gruntów pokrytych wodami. Grunty te zdefiniowano w art. 16 pkt 16 pr.wodn. m.in. jako grunty tworzące dna i brzegi cieków naturalnych, jezior oraz innych naturalnych zbiorników wodnych $\mathrm{w}$ granicach linii brzegu. Kopaliny wydobywane $\mathrm{z}$ wód $\mathrm{w}$ istocie są więc częścią gruntu pokrytego tymi wodami.

Wody i grunty pod nimi stanowią przy tym oddzielne przedmioty stosunków prawnych i praw, jakie do nich przysługują, aczkolwiek ze względu na specyfikę tych dóbr prawa te muszą pozostawać w ścisłym związku ${ }^{55}$. Nie zawsze wiodącą rolę w tym związku przypisuje się prawu do wody. Z punktu widzenia niniejszego opracowania odnotować wypada pogląd, że wszystkie współwystępujące elementy środowiska wodnego, w tym m.in. sama woda oraz złoża

${ }^{53}$ Ł. IWAŃsKI: Wybrane aspekty wydobywania kruszywa naturalnego ze złóż zlokalizowanych na lub pod dnem akwenów na śródladowych wodach powierzchniowych. W: Prawne aspekty gospodarowania..., s. 175-176.

${ }^{54}$ Tak A. Agopszowicz: Zarys systemu prawnego górnictwa..., s. 31 oraz np. R. Mikosz. W: System prawa prywatnego. T. 3: Prawo rzeczowe..., s. 474 i A. LIPIŃsKI: Z problematyki nielegalnego wydobywania kopalin. W: Prawne aspekty..., s. 266 - ten ostatni Autor zaznaczył nadto, że chodzi o wydobycie z dna zbiornika. Por. również G. Radecki: Wydobywanie kopalin..., s. 97 i powołaną tam literaturę.

${ }_{55}$ R. Mikosz. W: System prawa prywatnego. T. 3: Prawo rzeczowe..., s. 484. Zob. też np. M. Marszelewski, W. Marszelewski: Prawo powszechnego dostępu do wód publicznych i problemy z jego wykonywanie, ze szczególnym uwzględnieniem jezior. „Przegląd Prawa Ochrony Środowiska” 2014, nr 4, s. 147, B. Rakoczy: Prawo wlasności gruntów pod wodami. „Przegląd Prawa Ochrony Środowiska" 2014, nr 1, s. 122 i 127; IDEm: Nabycie własności gruntu pokrytego wodami. „Przegląd Prawa Ochrony Środowiska” 2015, nr 1, s. 10 i 20-21. 
kopalin, $\mathrm{w}$ świetle reguł prawa rzeczowego powinny być traktowane jako części składowe gruntu pokrytego wodą ${ }^{56}$. Znaczenie wody jako jednego z najważniejszych składników ekosystemu i szerokie jej zastosowanie w każdej dziedzinie życia oraz konieczność zapewnienia prawidłowej gospodarki wodnej sprawiają jednak, że prawo własności wód odbiega od klasycznych konstrukcji prawa cywilnego ${ }^{57}$. W szczególności w przypadku wód płynących własność ta wykonywana jest $\mathrm{w}$ interesie publicznym, co skutkuje połączeniem uprawnień właścicielskich z obowiązkami, które stanowią wręcz istotę tego prawa ${ }^{58}$. Wszelako Prawo wodne przewiduje zasadniczo dwie reguły dotyczące wód śródlądowych. Zgodnie z art. 216 ust. 1 pr.wodn. grunty pokryte takimi wodami płynącymi stanowią własność właściciela tych wód, z kolei odnośnie do śródlądowych wód stojących w art. 214 pr.wodn. przyjęto odwrotne rozwiązanie, przyznając własność właścicielowi nieruchomości, na której wody te się znajdują. Niezależnie jednak od tego, komu przysługuje prawo do gruntu pokrytego wodą śródlądową, oraz od tego, że jest to zawsze właściciel samej wody, z rozpatrywanego prawa wynika uprawnienie do wydobywania kopalin znajdujących się $\mathrm{w}$ tym gruncie, o ile złoża tych kopalin nie są objęte własnością górniczą ${ }^{59}$. W myśl art. 10 ust. 1 pr.g.g przedmiotem własności górniczej są bowiem złoża kopalin wymienionych w tym przepisie bez względu na miejsce ich występowania, podczas gdy złoża kopalin pozostałych, stosownie do art. 10 ust. 1 pr.g.g., są objęte prawem własności nieruchomości gruntowej, w tym lege non distinguente, tych pokrytych wodami śródlądowymi.

W powyższym kontekście nawiązać wypada do pojęcia uprawnień górniczych, oznaczającego, według doktryny, prawo podmiotowe do wydobywania kopalin, wywodzone z prawa do przestrzeni, w granicach której działalność ma być wykonywana ${ }^{60}$. Źródłem tych uprawnień może być - obok własności górniczej i ustanowionego celem rozporządzenia nią użytkowania górniczego oraz

${ }^{56}$ E. GNIEweK: W kwestii statusu prawnorzeczowego powierzchniowych wód plynacych $i$ wspótwystepujacych elementów naturalnych środowiska wodnego. „Acta Universitatis Wratislaviensis No 814 - Przegląd Prawa i Administracji” 1990, nr 21, zwłaszcza s. 80—81 i 84—85. Autor stwierdził, że częścią składową „gruntu podwodnego" są również złoża kopalin, choć zauważył, że nie podlegają one „raczej” prawu górniczemu, gdyż „wystarczy (...), że ich wydobywanie jest poddane prawu wodnemu" (s. 89-90).

${ }^{57}$ M. Marszelewski, W. Marszelewski: Problemy własności..., s. 30-31.

${ }^{58}$ B. Rakoczy: Własność wód w prawie polskim. „Przegląd Prawa Ochrony Środowiska” 2013, nr 1, s. 17 oraz 27.

${ }^{59}$ Wydaje się, że taki pogląd miał na myśli B. Rakoczy: Prawo własności..., s. 123 Autor stwierdził, że grunty pod wodami nie mogą być wykorzystane do innych celów niż te związane z istnieniem wód, oraz że odrębną sprawą, której omówienie w dalszej części tekstu jedynie zasygnalizował, pozostaje wydobycie piasku, żwiru i innych kopalin.

${ }^{60}$ Zob. np. A. Lipiński: Prawne podstawy geologii i górnictwa..., s. 40 i 49 - Autor słusznie określił przedmiot tych uprawnień szerzej - jako prawo podmiotowe do wykonywania wszelkiej działalności regulowanej Prawem geologicznym i górniczym. 
prawa własności nieruchomości gruntowej - prawo do wód, czy raczej powiązane z nim prawo do gruntów pokrytych wodami oraz prawo do szczególnego korzystania $\mathrm{z}$ wód ${ }^{61}$. To, $\mathrm{z}$ jakiego prawa wynika uprawnienie górnicze, nie ma jednak żadnego wpływu na przedmiot tych uprawnień, tj. to czy wydobywaniu podlega kopalina zalegająca $\mathrm{w}$ złożu. Z przyrodniczego punktu widzenia cała skorupa ziemska stanowi jednolitą całość, która wyłącznie z woli ustawodawcy została podzielona na części objęte różnymi, zindywidualizowanymi prawami podmiotowymi ${ }^{62}$. To, jakie prawo dotyczy takiej części, stanowi kwestię odrębną od kwalifikacji jej jako złoża kopaliny, sprowadzającej się do rozważenia, czy odpowiada ona definicji zawartej w art. 6 ust. 1 pkt 19 pr.g.g.

W toku wcześniejszych wywodów wykazano, że złoże takie, czyli naturalne nagromadzenie kopalin, na dnie czy w łożysku cieku wodnego występuje rzadko, choć jest to okoliczność faktyczna bardzo trudna do ustalenia. Wydobycie prowadzone od strony lustra wody ogranicza możliwość wystąpienia kolizji pomiędzy przepisami Prawa wodnego oraz Prawa geologicznego i górniczego, które do takich nienaturalnych nagromadzeń kopaliny nie może znaleźć zastosowania. Kolizja ta nie jest jednak całkowicie wykluczona, skoro nie każdy ciek czy zbiornik wody śródlądowej był w całości przedmiotem ingerencji ludzkiej, która nie zawsze oddziałuje na złoża położone pod dnem. Pytanie o sposób jej rozstrzygnięcia wydaje się zaś nadal pozostawać bez odpowiedzi, która byłaby kompleksowa i wolna od wątpliwości.

\section{Literatura}

Agopszowicz A.: Prawo wydobywania kopalin. „Ruch Prawniczy Ekonomiczny i Społeczny” 1966, nr 3, s. $21-45$.

Agopszowicz A.: Zarys systemu prawnego górnictwa. Katowice 1986.

Dobrowolski G., Lipiński A., Mikosz R., RADECKi G.: Gospodarowanie geologicznymi zasobami środowiska $w$ świetle zasady zrównoważonego rozwoju. Zagadnienia prawne. Katowice 2018.

GNIEwEK E.: W kwestii statusu prawnorzeczowego powierzchniowych wód plynacych $i$ wspótwystępujacych elementów naturalnych środowiska wodnego. „Acta Universitatis Wratislaviensis No 814 - Przegląd Prawa i Administracji” 1990, nr 21, s. 79-93.

IWAŃSKI Ł.: Wybrane aspekty wydobywania kruszywa naturalnego ze złóz zlokalizowanych na lub pod dnem akwenów na śródladowych wodach powierzchniowych. W: Prawne aspekty gospodarowania zasobami środowiska. Korzystanie z zasobów środowiska. Red. K. KARpus, B. Rakoczy, M. Szalewska. Toruń 2014, s. 169-185.

LIPIŃSKI A.: Komentarz do art. 6-9 ustawy z dnia 9 czerwca 2011 r. Prawo geologiczne i górnicze. „Prawne Problemy Górnictwa i Ochrony Środowiska” 2017, nr 1, s. 11—31.

\footnotetext{
${ }^{61}$ Por. R. Mikosz. W: System prawa prywatnego. T. 3: Prawo rzeczowe..., s. 473-474.

${ }^{62}$ A. LipiŃski: Własność złóż kopalin..., s. 177-178.
} 
LiPIŃSKi A.: Plan ruchu zakładu górniczego jako instrument ochrony środowiska. W: Administracja a środowisko. Prace dedykowane prof. zw. dr. hab. Markowi Górskiemu z okazji jubileuszu 45-lecia pracy naukowej. Red. A. Barczak, P. Korzeniowski. Szczecin 2018, s. $217-235$.

LipiŃsKi A.: Prawne podstawy geologii i górnictwa. Warszawa 2019.

LIPIŃsKi A.: Użytkowanie górnicze. Kraków 1996.

LipiŃski A.: Własność złóż kopalin. „Studia Cywilistyczne” 1977, T. 28, s. 175-200.

LIPIŃSKI A.: Z problematyki nielegalnego wydobywania kopalin. W: Prawne aspekty gospodarowania zasobami środowiska. Korzystanie z zasobów środowiska. Red. K. KARPUs, B. RAKOCZY, M. SZALEwSKA. Toruń 2014, s. 259-270.

Lipiński A., Mikosz R.: Ustawa prawo geologiczne i górnicze. Komentarz. Warszawa 2003.

Marszelewski M., Marszelewski W.: Jezioro Rododzierz - przykłady wykluczajacych sie rodzajów własności. „Przegląd Prawa Ochrony Środowiska” 2014, nr 1, s. 103-119.

Marszelewski M., Marszelewski W.: Prawo powszechnego dostępu do wód publicznych i problemy z jego wykonywanie, ze szczególnym uwzględnieniem jezior. „Przegląd Prawa Ochrony Środowiska" 2014, nr 4, s. 131-159.

Marszelewski M., Marszelewski W.: Problemy wtasności jezior w Polsce. „Przegląd Prawa Ochrony Środowiska" 2013, nr 3, s. 29-45.

Peodowski T.: Prawo górnicze. Warszawa 1961.

RADECKI G.: Oplata podwyższona za naruszenie warunków wydobywania piasków i żwirów na własne potrzeby. W: Prawne aspekty gospodarowania zasobami środowiska. Korzystanie z zasobów środowiska. Red. K. Karpus, B. Rakoczy, M. SzalewsKa. Toruń 2014, s. $291-311$.

RADECKI G.: Wydobywanie kopalin z wód powierzchniowych. „Prawne Problemy Górnictwa i Ochrony Środowiska" 2018, nr 1-2, s. 97-111.

Rakoczy B.: Nabycie własności gruntu pokrytego wodami. „Przegląd Prawa Ochrony Środowiska" 2015, nr 1, s. 9-22.

Rakoczy B.: Prawo własności gruntów pod wodami. „Przegląd Prawa Ochrony Środowiska” 2014, nr 1, s. 121-135.

Rakoczy B.: Własność wód w prawie polskim. „Przegląd Prawa Ochrony Środowiska” 2013, nr 1, s. $9-28$.

Schwarz H.: Prawo geologiczne i górnicze. Komentarz. T. 1. Wrocław 2013.

System prawa prywatnego. T. 3: Prawo rzeczowe. Red. E. GNIEWek. Warszawa 2013.

WóJCik-JACKowski S.: Wydobywanie kruszyw z tożyska wody płynacej. „Prawne Problemy Górnictwa i Ochrony Środowiska" 2019, nr 2, s. 61-71.

Zrównoważony rozwój jako czynnik determinujący prawne podstawy zarządzania geologicznymi zasobami środowiska. Red. G. DoBRowolski. Katowice 2016.

Gabriel Radecki

\section{Notion of extraction of minerals from deposits in context of water law}

\section{Summary}

Extraction of minerals is a subject of the Act of 9 June 2011 Geological and Mining Law as well as of the Act of 20 July 2017 Water Law. Author tries to compare and distinguish scopes of the both Acts, explaining meaning of crucial notions in the following order: mineral, deposit 
and extraction. He came to the conclusion that the Geological and Mining Law interferes with the Water Law only in the case when minerals constitute deposit located within surface waters. However, such a situation occurs rarely as a result of a human impact on waters, since pursuant to art. 6 item 1 point 19 of the Geological and Mining Law a mineral deposit is defined as a natural accumulation of minerals.

Key words: mineral, deposit of minerals, extraction, special use of waters, surface waters

Габриэль Радецкий

\section{Концепция добычи полезных ископаемых из месторождений в контексте водного права}

Резюме

Добыча полезных ископаемых регулируется Геологическим и горным правом от 9 июня 2011 г., а также Водным кодексом от 20 июля 2017 г. Автор сравнивает и выделяет сферу действия обоих законодательных актов, объясняя ключевые понятия в следующем порядке: полезные ископаемые, месторождение и добыча. Он приходит к выводу, что Геологическое и горное право и Водный кодекс пересекаются только тогда, когда полезные ископаемые образуют месторождение, расположенное в поверхностных водах. Однако такая ситуация редко возникает в результате действий человека, поскольку согласно пп. 19 п. 1 ст. 6 Геологического и горного права месторождение полезных ископаемых определяется как естественное скопление полезных ископаемых.

Ключевые слова: полезные ископаемые, месторождение полезных ископаемых, добыча полезных ископаемых, специальное использование воды, поверхностные воды

Gabriel Radecki

\section{II concetto di estrazione di minerali dai giacimenti nel contesto della legge sull'acqua}

Sommario

Riassunto: L'estrazione di minerali è soggetta alla legge del 9 giugno 2011 - Legge geologica e mineraria ed anche legge del 20 luglio 2017 - Legge sull'acqua. L'autore cerca di confrontare e differenziare l'ambito di entrambi gli atti, spiegando i termini chiave, nel seguente ordine: minerale, deposito ed estrazione. Giunge alla conclusione che la legge geologica e mineraria e la legge sull'acqua si intersecano solo quando i minerali formano un deposito situato in acque superficiali. Tuttavia, tale situazione capita raramente come risultato dell'attività umana, poiché secondo l'art. 6, par.1, c.19, della legge geologica e mineraria, un giacimento minerario è definito come un accumulo naturale di minerali.

Parole chiave: miniere, deposito di minerali, estrazione mineraria, utilizzo particolare di acque, acque superficiali 